\section{Use of multi-criteria analysis (MCA) for supporting community forest management}

\author{
Chiranjeewee Khadka, Harald Vacik
}

Sustainable forest management usually involves the use of criteria and indicators (C\&I) allowing the monitoring, reporting and assessment of management activities at national, regional and forest management unit levels. Experiences of such concepts are scarce in Nepal, particularly with regard to the evaluation of management activities within a Multi-Criteria Analysis (MCA) framework. In this contribution we describe how a MCA approach can be used to efficiently exploit information, knowledge, and preferences of stakeholders to address community forest management problems. Beside rating and ranking techniques, the Analytic Hierarchy Process (AHP) is used to examine the importance of six criteria and forty-four indicators in a sustainable forest management context with a broad range of stakeholder groups. An evaluation of four management strategies in the Shree Gyneshwar community forest user group allows to demonstrate the relevance of changing priorities for different criteria. A passive adaptive management strategy focusing on a multiple use of natural resources and the introduction of production-oriented measures were identified as the most preferable option. The results of this study show that the multi-criteria analysis approach, and in particular the AHP, can assist decision-makers in efficiently evaluating management problems and generating ideas for the long-term strategic planning process of community forest management, even under complex socio-economic and ecological conditions. In that context, compromise solutions enjoy a higher possibility of being successful, taking into account the different views of stakeholder groups.

Keywords: Multiple-criteria decision-making, Sustainable forest management, AHP, Criteria and indicators, Community forestry, Nepal

\section{Introduction}

Approaches in community forestry management

Community forestry has shifted from traditional participatory, to participatory and collaborative management approaches that integrate local and scientific knowledge (e.g., Walters 1986, Maser 1996, Schreiber et al. 2004). The involvement of stakeholders to manage the forests as community forestry

$\square$ University of Natural Resources and Life Sciences, Department of Forest and Soil Sciences, Institute of Silviculture, Peter Jordan StraBe 82, A-1190, Vienna (Austria)

@ Chiranjeewee Khadka

(chiranjeewee.khadka@boku.ac.at)

Received: Oct 02, 2011 - Accepted: Feb 12, 2012

Citation: Khadka C, Vacik H, 2012. Use of multi-criteria analysis (MCA) for supporting community forest management. iForest 5 : 60-71 [online 2012-04-30] URL:

http://www.sisef.it/iforest/ contents/? id=ifor0608-009

Communicated by: Marco Borghetti terms of sustained yield was radically expanded (Glück 1995). Sustainable forest management is defined as "stewardship and use of forests and forest land in a way, and at a rate, that maintains their biodiversity, productivity, generation capacity, vitality, and their potential to fulfill now and in the future, relevant ecological, economic, and social functions at local, national, and global levels [...]" (MCPFE 1993). However, there exists a wide variety of planning and management approaches which comprise different schools of thought and allow different impacts. Therefore, in community forest management the practical implementation of the planning approaches is often highly debated and a promising approach is hardly identified. In a traditional participatory planning and management approach, goals are set and one management strategy is selected as the optimal one (Linkov et al. 2006). It has been often criticized that in such a setting process information sharing is restricted, stereotypes are reinforced, and that a limited public involvement in the plan development, as well as win-lose solutions, are generally promoted (Friedmann 1973, Susskind \& Cruiskshank 1987, Blahna \& Yonts'-Shepard 1989, Maser 1996, Wondolleck \& Yaffee 2000). Walters (1986) introduced the concept of an evolutionary ("trial and error") approach, which is closely linked to the traditional participatory approach, but starts with a haphazard set of choices and progressively winnows these down to a subset to improve results. This approach can produce holistic and equitable solutions with the necessary support to be implemented (Susskind \& Ozawa 1985, Gray 1989, Carpenter 1991, Potapchuk 1991, Wondolleck \& Yaffee 2000).

The collaborative-based planning approaches described in the literature are rich in participatory tools and methods aiming to support natural resource management, including co-management (e.g., Reed 1995, Paulson 1998) and adaptive management (e.g., Schreiber et al. 2004). In the literature, co-management is described as a planning approach which supports formal arrangements between governments and local groups involving institution building (e.g., Jentoft 1985) and emphasizes the sharing of rights, responsibilities, and power between different levels and sectors of government and civil society (Armitage et al. 2007). Adaptive management approaches involve the generation of alternative hypotheses, assess the value of additional information, develop models for future learning, formulate policy options and support the identification of criteria to facilitate evaluation and comparison among options (Hilborn \& Walters 1992). Adaptive management systematically integrates results of previous interventions to 
iteratively improve and accommodate change by learning from the outcomes of experimented practices (McDonald-Madden et al. 2010) and promotes learning-based decision making, monitoring and action (Holling 1978, Williams 2011a), Thus learning through ad hoc trial and error is replaced with learning by careful design and testing (Walters 1997). Adaptive management has explicit structure, including careful elucidation of goals, identification of alternative management objectives, hypotheses of causation, and procedures for the collection of data followed by evaluation and reiteration (Allen et al. 2011). Within the adaptive management approach two types (active and passive) can be distinguished which comprise the setting of goals, modeling the system, and selecting and implementing a management strategy (Linkov et al. 2006). Lindenmayer et al. 2011 recently proposed an adaptive monitoring approach that links the development of conceptual models, setting questions, making a experimental design, collecting, analyzing and interpreting data iteratively, and that can be applied to all kinds of monitoring, including question-driven, passive and mandated monitoring programs. Passive adaptive management applies historical data to design and implements management strategies ("single best estimate") at the same time, with the management decision being made assuming this model is correct (Walters \& Hilborn 1978 Linkov et al. 2006). "Single best estimate" should be actually considered outside the realm of monitoring for adaptive management (Corona \& Scotti 2011). In active adaptive management, multiple experimental alternatives are examined, and feedback loops allow the reiteration of alternatives as well as goals and criteria weightings (Linkov et al. 2006), requiring to measure the initia state of the systems and to monitor trends over time to track system responses to management practices (Corona \& Scotti 2011), which are distinguished primarily by the degree to which they emphasize the reduction of uncertainty (Williams 2011a). Adaptive co-management combines the dynamic learning characteristic of adaptive management (e.g., Holling 1978) with the features of collaborative management (e.g., Buck et al 2001)

Supporting community forestry in Nepal In making plans and managing natural resources, Multi-Criteria Analysis (MCA) helps to consolidate the multiple views and knowledge of stakeholders to support decision-making in complex environments (Kangas et al. 2006, Mendoza \& Martins 2006, Martins \& Borges 2007). MCA techniques have proved to be useful in structuring forest management problems (Ananda \& Herath 2005), supporting participatory de- cision-making (Nordström et al. 2010), negotiation, and mediation processes (Bojórquez-Tapia et al. 2005, Antunes et al. 2006). Additionally, Criteria and Indicators (C\&I) provide a common framework to describe, conceptualize, organize, and interpret information related to sustainable forest management (Woodley et al. 1998, Prabhu et al. 1999, Wijewardana 2008). They have proved to be a useful communication tool among stakeholders and local communities (Ritchie et al. 2000). Prabhu et al. (1996, $2000,2001)$ proposed the combined use of C\&I sets and MCA and their applicability for the development of adaptive management programs. The hierarchical structure of defining indicators allows a complex problem to be broken down into manageable elements that can lend themselves to formal analysis (Mendoza \& Prabhu 2003). In this context the Analytic Hierarchy Process (AHP) is a robust, ratio-scaled MCA method for analyzing complex decisions with multiple attributes (Saaty 1977). The AHP has been applied to elicit public preferences in a vast range of natural resource policy areas, including forest management (Schmoldt et al. 2001, Mardle et al. 2004), and was applied in multi-objective forest management for structuring and solving complex decision problems (Malczewski et al. 1997, Kangas 1999, Vacik \& Lexer 2001).

Community forestry in Nepal can be described as a laboratory for participatory resource management, where collaboration and coordination among all stakeholders is practiced daily (Khadka \& Vacik 2008). However, the existing collaborative planning approaches in community forest management in Nepal are currently not utilizing MCA for evaluating forest management. Although Hjortsø et al. (2006) applied multiple-objective programming and goal programming for a land-use planning case in the protected area-buffer zone management of the Chitwan National Park, they failed to analyze the decision problem in a collaborative manner. As the concept of C\&I has emerged in an increasing number of initiatives at global, national and forest management unit level, it has been applied in community forest management in Nepal as well (Khadka \& Vacik 2012). However, a number of applications evaluating forest planning and management approaches with MCA techniques describe limits in the practical implementation (Mendoza \& Prabhu 2000, 2003, 2005, Herath 2004, Wolfslehner et al. 2005). From this study it became evident that appropriate management requires: (i) harmonizing and integrating different datasets; (ii) selecting the right indicators; (iii) fitting the right concept to the right scale; and (iv) integrating data, indicators and concepts into systems that allow both a high level of participation and flexibility in application to different ques- tions (Fürst et al. 2010).

This study intends to support the practical implementation of community forest management in the Shree Gyneshwar Community Forest in the central development region, Nepal, by utilizing MCA techniques for evaluating different management strategies for community forest management (CFM). The objectives of this work were:

1. to assess the relative importance of a proposed set of C\&I with respect to sustainable forest management, by the elicitation of stakeholders preferences;

2. to evaluate perceptions of the overall performance of community forest management strategies by the use of Analytic Hierarchy Process (AHP);

3. to perform a sensitivity analysis to identify an overall compromise option in the case study area;

4. to draw policy implications for supporting community forest management in Nepal.

\section{Multi-Criteria Analysis (MCA) for supporting community forest management}

\section{Case study area: Shree Gyneshwar} community forest

The Shree Gyneshwar Community Forest (SGCF) is located in Mangalpur Village Development Committee (VDC), Chitwan district of central development region, Nepal. It covers an area of 208 hectares and 2300 Households (Hhs - year 2009). Gyneshwar $\mathrm{CF}$ lies in sub-tropical lowlands of the inner terai region, located at the alluvial plain of Narayani river, and is dominated by young stands (25 years) and riverine forests. Main species are: Sissoo (Delbergia sissoo Roxb.), Gutel (Trewia nudiflora L.), Khayar (Acacia catechu L.f. Willd.), Karma (Adina cardifolia Hook.), Ipil Ipil (Leucaena leucocephala [Lam.] de Wit) and Bakaino (Melia Azedirach L.). Climatic conditions of this subtropical region are relatively warm: highest temperatures reach $38{ }^{\circ} \mathrm{C}$ during the winter season and drop to a minimum of $6^{\circ} \mathrm{C}$ in the post-monsoon period (October to January), when dry northerly winds from the Himalaya and Tibetan Plateau are prevalent (Bolton 1975). Mean annual rainfall is $2400 \mathrm{~mm}$ with about $90 \%$ falling in the monsoon from June to September. The soils of this area are highly variable but mostly sandy and alluvial soil.

Owing to human settlements, increasing fuel (wood) demands, population pressures, and the conversion of forest land to agriculture land and illegal practices, the area was completely deforested in the 1980s. In 1981 the Timber Corporation of Nepal (TCN) initiated a plantation programme in this area with Sissoo (Dalbergia Sissoo), and handed over the plantation areas to the District Forest Office (DFO), Chitwan. Gyneshwar CF 
runs its own community nursery consisting of a variety of fast growing and multi-purpose tree species, e.g., Sissoo (Dalbergia sissoo), Bakaino (Melia azedarach), Ipil-ipil (Leucaena leucocephala), and others. Local associates and farmers are trained for plantation and other forest management activities. $\mathrm{CF}$ has tremendously worked on biodiversity conservation, wildlife habitat management and plantation work and invested lots of efforts to restore the forest condition. They are highly motivated to conserve biodiversity, protect the river-bank and improve forest condition through multi-purpose forest management system and promote eco-tourism and forest recreation activities in their forest.

The governmental local authorities adapted the traditional participatory approaches with the consultation of local users, and formed the constitution and operational plan with an ad hoc committee, without specifying objectives and activities, and handed over the forests to local communities in 2001. After that, several participatory tools (e.g., social mapping, stakeholder analysis, participatory resource mapping, historical trend and seasonal calendar) have been applied during the amendment of constitution and operational plan at period 2006 and 2009, which increased users' awareness of forest protection, management and utilization of forest resources. As the demand of local users for natural resources is quite high, there is a need to increase the forest's productivity by applying a regular management. In order to support the Community Forest User Group (CFUG) in moving towards a more efficient and effective management a Multi-Criteria Analysis (MCA) approach was initiated.

\section{Methods}

Multi Criteria Analysis (MCA) refers to a suite of techniques in which multiple values reflecting different objectives are quantified and used to provide a decision outcome (Gregory 2000). In this study, a methodological approach was adopted that seek to take explicit account of multiple criteria in helping individuals or groups explore decisions that matter (Belton \& Stewart 2002). Mendoza \& Prabhu $(2000,2005)$ describe a number of features that make MCA valuable for community based forest management, in that it accommodates individual concerns and opinions of a number of stakeholders by a set of criteria being measured and evaluated simultaneously. For applying the MCA process to the case study, five phases were distinguished: (i) awareness building, (ii) criteria and indicators development, (iii) elicitation of preferences, (iv) formulating of forest management options, and (v) evaluation of management options (Fig. 1).

In the awareness building phase the community forest user group (CFUG) started to develop a vision and goals based on the re-

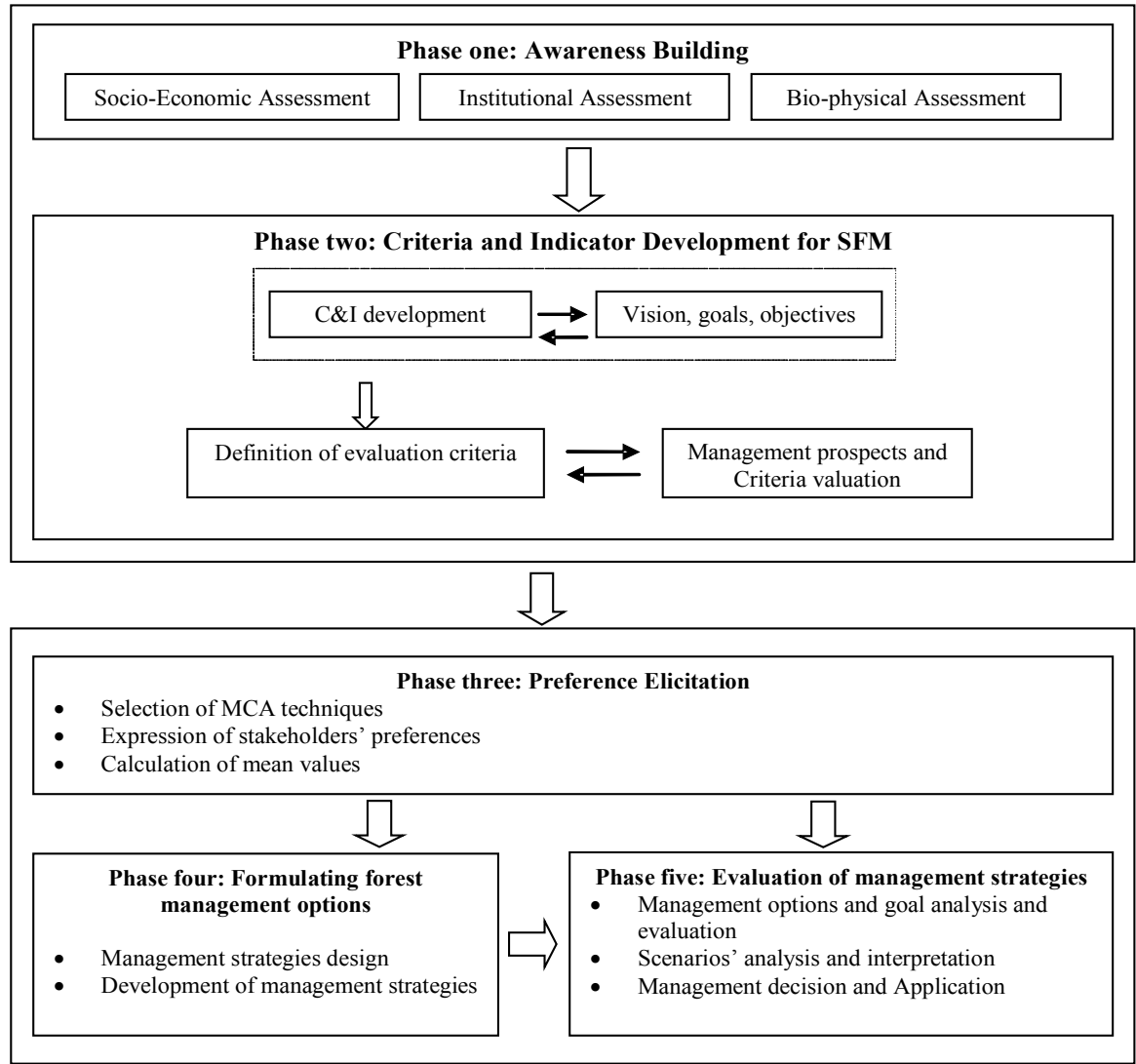

Fig. 1 - Application of Multi-Criteria Analysis (MCA) in evaluating Community Forest Management (CFM).

sults of studies on the socio-economic, institutional, historical, policy and bio-physical conditions of the case study site. The CFUGs and researcher jointly identified and classified stakeholders' interests, and their roles and involvement in the decision-making process. In the C\&I development phase the participants discussed the main principles of Sustainable Forest Management (SFM) and negotiated objectives and outcomes for different levels. The research team and local facilitators organized 20 hamlet-level meetings to derive the opinions and experiences from all stakeholder groups. The number of participants in each tole/hamlet varied between 20 and 25 persons. In the C\&I development workshop, some 71 users arranged in 12 stakeholder groups developed and assessed a set of 6 criteria and 44 indicators. A series of workshops were held in the Gyneshwar CFUG, from April 2007 to March 2009. For the case study, participants were selected by the following criteria: executive committee of forest user groups (who have executive power for decision-making and implementation work); general users (e.g., interested in resource management or affected by decisions in the areas); advisory committee members (e.g., having expertise on the historical background of the forest or influence the planning process) and local facilitators (engaging stakeholder in the process), with a total of 72 participants (see also Khadka \& Vacik 2012). The representatives of the stakeholder groups had sound knowledge of the region and the community forest user group was selected by the executive committee of the Shree Gyneshwar CFUG.

At the preference elicitation stage, the comments and inputs of stakeholders were accommodated to refine the set of criteria and indicators. A final set was used throughout all group meetings for weighting consistency purposes. Ranking, rating and pairwise comparison techniques, which are commonly used in C\&I assessment studies, have been applied for preference elicitation (see Prabhu et al. 1999, Schmoldt et al. 2001, Ramanathan 2001, Vacik et al. 2001). In this study the participants were instructed to express their weights for each criterion by applying rating and ranking techniques. For the rating a score between 0 and 9 was assigned to each element and the ranks were assigned following a 9-point scale, depending on the number of indicators related to each criterion. Moreover, pairwise comparisons were done by the local facilitators based on the ordinal input (ranking, rating) provided by the stakeholder groups according to each single indicator, and the priorities were calculated using the Eigenvalue method (Saaty 1977). 
Tab. 1 - Selected characteristics of different management approaches in community forest management.

\begin{tabular}{|c|c|c|c|}
\hline Key elements & $\begin{array}{c}\text { Traditional } \\
\text { participatory } \\
\text { approaches }\end{array}$ & $\begin{array}{c}\text { Passive adaptive } \\
\text { management } \\
\text { approaches }\end{array}$ & $\begin{array}{c}\text { Active adaptive } \\
\text { management approaches }\end{array}$ \\
\hline $\begin{array}{l}\text { Public } \\
\text { consultation }\end{array}$ & Rare & $\begin{array}{l}\text { Minimal public con- } \\
\text { sultation and less } \\
\text { interaction }\end{array}$ & $\begin{array}{l}\text { Maximum public participa- } \\
\text { tion and intensive interactive } \\
\text { and negotiations }\end{array}$ \\
\hline $\begin{array}{l}\text { Forest manage- } \\
\text { ment objectives }\end{array}$ & $\begin{array}{l}\text { Single objective } \\
\text { (Protection) }\end{array}$ & $\begin{array}{l}\text { objectives related to } \\
\text { protection, provide } \\
\text { forest products to } \\
\text { users regularly }\end{array}$ & $\begin{array}{l}\text { Short-, medium- and long- } \\
\text { term objectives related to } \\
\text { resource utilization, multiple- } \\
\text { objectives }\end{array}$ \\
\hline $\begin{array}{l}\text { Primary forest } \\
\text { management } \\
\text { system }\end{array}$ & $\begin{array}{l}\text { Protection-oriented, } \\
\text { extensive manage- } \\
\text { ment }\end{array}$ & $\begin{array}{l}\text { Mainly continuous } \\
\text { cover system, forest is } \\
\text { planning unit }\end{array}$ & $\begin{array}{l}\text { Single-tree selection system } \\
\text { and age-class system in } \\
\text { blocks }\end{array}$ \\
\hline $\begin{array}{l}\text { Management } \\
\text { responsibility }\end{array}$ & $\begin{array}{l}\text { Executive } \\
\text { committee (EC) }\end{array}$ & $\begin{array}{l}\text { Executive } \\
\text { committee (EC) }\end{array}$ & Sub-committee and EC \\
\hline $\begin{array}{l}\text { Policy documents } \\
\text { preparation }\end{array}$ & $\begin{array}{l}\text { Government Orga- } \\
\text { nization }(\mathrm{GO}) \text { and } \\
\text { Elite members }\end{array}$ & $\begin{array}{l}\mathrm{GO} \text {, elite and main pos } \\
\text { ition holders of } \mathrm{EC}\end{array}$ & $\begin{array}{l}\text {-N/GO, elite, EC members, } \\
\text { and general users }\end{array}$ \\
\hline $\begin{array}{l}\text { Representation/ } \\
\text { Leadership in } \\
\text { FUG }\end{array}$ & Ad hoc committee & $\begin{array}{l}\text { Exclusive, Committee } \\
\text { domination }\end{array}$ & $\begin{array}{l}\text { Inclusive, democratic system } \\
\text { and leadership development }\end{array}$ \\
\hline $\begin{array}{l}\text { Decision-making } \\
\text { process/power- } \\
\text { sharing }\end{array}$ & $\begin{array}{l}\text { Authority and } \\
\text { government bodies }\end{array}$ & EC members & $\begin{array}{l}\text { Devolution within EC mem- } \\
\text { bers and Sub-action groups }\end{array}$ \\
\hline $\begin{array}{l}\text { Monitoring } \\
\text { system }\end{array}$ & $\begin{array}{l}\text { Monitoring by } \\
\text { government } \\
\text { authorities }\end{array}$ & $\begin{array}{l}\text { Jointly by government } \\
\text { bodies, Committee } \\
\text { members and staff }\end{array}$ & Self-monitoring systems \\
\hline
\end{tabular}

Each participant had the chance to argue different opinions in their own group and in the plenary as well, and a consensus had to be found based on the different preferences of the members within one group. As a consequence, the individual judgments of each member within a group were used to formulate one single representative judgment for the entire group in a negotiation process However, in order to allow a synthesis of the

individual group priorities within the AHP, the judgments had to be combined in a manner so that the reciprocal of the synthesized judgments is equal to the synthesis of the reciprocals of these judgments (Saaty 2008). If groups or individuals had different priorities of importance, it was suggested that their synthesized judgments (final outcomes) should be raised to the power of their priorities, leading to calculate the geometric mean

Tab. 2 - Priorities for the criteria based on geometric mean of the synthesized stakeholder group judgments.

\begin{tabular}{llcccc}
\hline \multicolumn{1}{c}{ Criteria } & $\begin{array}{c}\text { Advisory } \\
\text { members } \\
\text { groups }\end{array}$ & $\begin{array}{c}\text { CFUGC } \\
\text { members } \\
\text { groups }\end{array}$ & $\begin{array}{c}\text { General } \\
\text { users } \\
\text { groups }\end{array}$ & $\begin{array}{c}\text { Local } \\
\text { facilitators } \\
\text { groups }\end{array}$ & $\begin{array}{c}\text { All stake- } \\
\text { holders }\end{array}$ \\
\hline $\begin{array}{l}\text { C1: Compliance with all inter- } \\
\text { national, national and local }\end{array}$ & $0.2474^{*}$ & 0.1339 & 0.0870 & 0.0788 & 0.1175 \\
$\begin{array}{l}\text { laws under policy framework } \\
\begin{array}{l}\text { C2: Silvicultural practices and } \\
\text { other management systems }\end{array}\end{array}$ & 0.1234 & 0.1725 & 0.1573 & $0.2699^{*}$ & 0.1799 \\
$\begin{array}{l}\text { C3: Encourage multiple forest } \\
\text { products and services / Envi- } \\
\text { ronmental and Forest health }\end{array}$ & 0.2110 & $0.2163^{*}$ & 0.1827 & 0.1746 & 0.1919 \\
$\begin{array}{l}\text { C4: Appropriate enhancement } \\
\text { of management plan }\end{array}$ & 0.1404 & 0.1054 & 0.1064 & 0.0909 & 0.1080 \\
$\begin{array}{l}\text { C5: Long-term social and eco- } \\
\text { nomic well-being and com- }\end{array}$ & 0.1440 & 0.1662 & $0.2526^{*}$ & 0.2028 & 0.1903 \\
$\begin{array}{l}\text { munity relations } \\
\begin{array}{l}\text { C6: Regular monitoring and } \\
\text { assessment }\end{array}\end{array}$ & 0.1202 & 0.1713 & 0.1870 & 0.1687 & 0.1594 \\
\hline
\end{tabular}

of the group priorities for that purpose (Saaty 2008).

Based on the discussions in the preference elicitation workshops the CFUG developed management strategies to improve the livelihood of the poor and promote social inclusion. Each stakeholder group was asked to express their favorite measures for improving the overall situation and all actions were complied in four management strategies (Tab. 4). The groups had different perceptions on the magnitude of improvement of the forest conditions and livelihood of rural users. The stakeholders were asked for a qualitative assessment of the strategies using a five-point scale similar to other studies (Prato \& Herath 2007, Wolfslehner \& Vacik 2008): very high improvement to the current situation $(+++)$; high improvement $(++)$; fairly good improvement $(+)$; no significant improvement at all (0); and in conflict with the current SFM objectives (-). The qualitative evaluation of stakeholder groups was related to the available information of context studies (e.g., socio-economic assessment, bio-physical assessment, institutional assessment, and constitution and operational plan) but in some cases stakeholders were uncertain about a likely improvement (stating “?”). A final decision on the performance of the management strategies was made by members of the executive committee and approved by the general assembly of forest user groups.

The presentation of the findings of the case study focuses on the preference elicitation (stage three), formulating forest management options (stage four) and evaluation of management strategies (stage five) in order to demonstrate the practical implementation of the MCA approach (Fig. 1).

\section{Adopting the multi-criteria analysis approach}

\section{Preference elicitation}

The stakeholder groups comprising a total of 71 users were classified into twelve subgroups (15 Advisory members in 3 groups, 13 CFUGC members in 2 groups, 23 general members in 3 groups, 20 local facilitators in 4 groups) and asked to assess each criterion according to its perceived importance, with respect to sustainable community forest management and improvement of their livelihood. According to the judgements $(n=12)$ of the four different stakeholder groups for each criterion, the criteria for environmental and forest health $(\mathrm{C} 3)$ and community relations (C5) were found to be the most relevant, followed by silvicultural prescriptions (C2) and monitoring (C6). The management plan (C4) and policy framework (C1) had less importance. Tab. 2 indicates that the stakeholder groups expressed their priorities for the criteria differently as each group 
Tab. 3 - Preferences of criteria based on rating, ranking and pairwise comparisons (PWC) methods ( $\mathrm{n}=12)$. (a): indicates the means for the most preferred indicator under each criterion.

\begin{tabular}{|c|c|c|c|c|c|}
\hline Criteria/Indicators & $\begin{array}{c}\text { Arith. mean } \\
\text { of rating } \\
(0-9)\end{array}$ & $\begin{array}{l}\text { SD of } \\
\text { rating }\end{array}$ & $\begin{array}{c}\text { Arith. mean } \\
\text { of ranking } \\
(1-n)\end{array}$ & $\begin{array}{l}\text { SD of } \\
\text { ranking }\end{array}$ & $\begin{array}{c}\text { Gmean of } \\
\text { priorities } \\
\text { (PWC) }\end{array}$ \\
\hline $\begin{array}{l}\text { Criterion 1: Compliance with all international, national and local laws } \\
\text { under policy framework }\end{array}$ & 6.5 & 1.09 & 4.00 & 2.26 & 0.1175 \\
\hline I1.1 Payment of applicable taxes and fees & 6.00 & 1.21 & 3.33 & 1.44 & 0.1905 \\
\hline I1.2 Respect for and enforcement of national and local laws & 6.83 & 1.03 & 2.17 & 1.34 & 0.1427 \\
\hline I1.3 Evaluation of conflicting laws & 5.75 & 1.06 & 3.42 & 1.62 & 0.1276 \\
\hline I1.4 Protection from illegal and unauthorized activities & $7.17^{\text {(a) }}$ & 0.83 & $1.42^{\text {(a) }}$ & 0.79 & $0.2413^{\text {(a) }}$ \\
\hline I1.5 Consultation with professional policy-makers and experts & 5.75 & 1.06 & 3.25 & 1.91 & 0.1153 \\
\hline $\begin{array}{l}\text { I1.6 Documentation and reporting system to the appropriate } \\
\text { authorities }\end{array}$ & 5.58 & 1.24 & 3.58 & 2.02 & 0.1165 \\
\hline Criterion 2: Silvicultural practices and other management systems & 7.58 & 1.08 & 2.33 & 1.78 & 0.1799 \\
\hline I2.1 Silvicultural management prescription & 6.58 & 2.39 & 2.92 & 1.98 & 0.1404 \\
\hline I2.2 Estimation of forest harvest & 6.17 & 1.11 & 4.00 & 1.35 & 0.0962 \\
\hline I2.3 Specific harvesting guidelines and techniques & 6.17 & 1.11 & 4.00 & 1.35 & 0.0955 \\
\hline I2.4 Ensuring the number of old trees in forest stands & 6.00 & 0.85 & 4.50 & 1.51 & 0.0865 \\
\hline I2.5 Promotion of the plantation area & $7.42^{\text {(a) }}$ & 1.08 & $1.58^{\text {(a) }}$ & 1.16 & $0.1683^{\text {(a) }}$ \\
\hline I2.6 Development and layout of plantations & 7.33 & 1.07 & 1.67 & 1.15 & 0.1544 \\
\hline I2.7 Control of encroachment and grazing & 4.58 & 1.08 & 6.67 & 1.92 & 0.0564 \\
\hline I2.8 Control of forest fire and minimization of forest damage & 4.58 & 1.31 & 6.17 & 2.37 & 0.0570 \\
\hline I2.9 Promotion of use of suitable tree species & 6.25 & 1.60 & 3.17 & 2.41 & 0.1000 \\
\hline $\begin{array}{l}\text { Criterion 3: Encourage multiple forest products and services and a wide } \\
\text { range of environmental and forest health }\end{array}$ & 7.67 & 0.49 & 1.67 & 0.78 & 0.1919 \\
\hline I3.1 Maintain ecosystem diversity & 6.08 & 1.31 & 4.25 & 1.66 & 0.0801 \\
\hline I3.2 Native species diversity & 6.08 & 0.90 & 4.83 & 1.40 & 0.0792 \\
\hline I3.3 Ecological assessment and diagnosis & 6.08 & 1.16 & 4.83 & 1.11 & 0.0886 \\
\hline I3.4 Promote environment impact assessment & 6.08 & 1.16 & 5.08 & 1.24 & 0.0867 \\
\hline I3.5 Maintain biodiversity & 7.75 & 1.36 & 1.75 & 1.22 & 0.1468 \\
\hline I3.6 Support conservation measures & $8.08^{\text {(a) }}$ & 0.79 & $1.25^{\text {(a) }}$ & 0.87 & $0.1775^{\text {(a) }}$ \\
\hline I3.7 Wildlife management and habitat & 7.58 & 1.00 & 2.00 & 1.76 & 0.1526 \\
\hline I3.8 Water courses and other wetlands & 7.42 & 1.08 & 2.67 & 1.97 & 0.1404 \\
\hline Criterion 4: Appropriate enhancement of management plan & 7.25 & 1.6 & 2.17 & 1.70 & 0.1080 \\
\hline I4.1 Ensure users' participation in planning and implementation & $7.50^{\text {(a) }}$ & 1.09 & $1.67^{\text {(a) }}$ & 1.37 & $0.2231^{\text {(a) }}$ \\
\hline I4.2 Implement management plans & 6.67 & 0.78 & 2.75 & 1.29 & 0.1265 \\
\hline I4.3 Revision and timeliness of management plan & 6.58 & 0.67 & 2.83 & 1.27 & 0.1176 \\
\hline I4.4 Review/approval of plan & 6.58 & 0.67 & 2.83 & 1.27 & 0.1176 \\
\hline $\begin{array}{l}\text { I4.5 Develop management guidelines of enterprise development and other } \\
\text { management plans }\end{array}$ & 6.67 & 0.78 & 3.58 & 2.27 & 0.1323 \\
\hline I4.6 Public availability of management plan & 6.83 & 1.27 & 3.25 & 2.22 & 0.1378 \\
\hline I4.7 Knowledge of forest resource use and management plan & 5.92 & 1.08 & 6.08 & 1.62 & 0.0980 \\
\hline $\begin{array}{l}\text { Criterion 5: Long-term social and economic well-being of local } \\
\text { communities under community relations }\end{array}$ & 6.08 & 1.08 & 4.58 & 1.00 & 0.1903 \\
\hline I5.1 Promote participatory decision-making and social inclusion & $7.67^{\text {(a) }}$ & 1.87 & $1.67^{\text {(a) }}$ & 0.98 & $0.1587^{\text {(a) }}$ \\
\hline I5.2 Ensure transparency & 7.17 & 1.64 & 2.42 & 1.08 & 0.1280 \\
\hline I5.3 Ensure collaboration within and among stakeholders & 6.75 & 0.97 & 3.75 & 2.56 & 0.1074 \\
\hline I5.4 Staff safety and health & 6.42 & 0.79 & 4.75 & 2.45 & 0.0902 \\
\hline I5.5 Special provision for unprivileged groups & 7.25 & 1.60 & 2.50 & 1.31 & 0.1266 \\
\hline I5.6 Encourage local processing and new markets & 6.17 & 1.03 & 5.00 & 1.76 & 0.0762 \\
\hline I5.7 Sharing in economic benefits of forest use & 6.50 & 1.57 & 3.75 & 1.60 & 0.0903 \\
\hline I5.8 Income-generation activities & 6.58 & 1.56 & 3.92 & 1.88 & 0.0924 \\
\hline I5.9 Use of trained and experienced persons & 6.25 & 0.45 & 5.08 & 2.31 & 0.0833 \\
\hline Criterion 6: Regular monitoring and assessment & 7.17 & 1.11 & 2.33 & 1.30 & 0.1594 \\
\hline I6.1 Monitoring requirement & $7.17^{\text {(a) }}$ & 1.40 & $1.50^{\text {(a) }}$ & 0.90 & $0.2415^{(a)}$ \\
\hline I6.2 Frequency and intensity of monitoring & 6.75 & 1.42 & 1.92 & 1.00 & 0.2065 \\
\hline I6.3 Data collection and use & 5.92 & 0.90 & 3.08 & 1.16 & 0.1250 \\
\hline I6.4 Incorporation of monitoring results into management plan & 6.33 & 1.15 & 2.33 & 1.30 & 0.1640 \\
\hline I6.5 Availability of monitoring results & 7.00 & 1.13 & 1.92 & 1.31 & 0.1996 \\
\hline
\end{tabular}


identified its own favorite. (C1) was preferred by the Advisory Members, (C2) by the local facilitators, (C3) by the CFUGC members, and (C5) by the general users, respectively. (C4) was not prioritized by any of the stakeholder groups.

Tab. 3 presents the derived relative weights and standard deviation of the preference values for the indicators using rating (columns 2 and 3), ranking (columns 4 and 5) and geometric mean of the priorities of the pairwise comparisons technique (column 6). The results obtained from the 12 stakeholder groups by rating, ranking and pairwise comparisons do not indicate large differences, depending on the preference elicitation technique. In addition, the small variability in the individual preferences reflects a high level of similarity among the twelve stakeholder groups. The indicators I1.4, I2.5, I3.6, I4.1, I5.1 and I6.1 were rated with first priority by all methods. However, most of the indicators ranked second or third based on priorities received from different techniques. However, all activities related to protection measures (illegal and unauthorized activities, plantations, conservation measures) and participatory management have been listed with high priority.
Formulating forest management options The Shree Gyneshwar CFUGs mostly adopted conservative and protection oriented management strategies where the collection of dead, dying and diseased trees for fuel was undertaken, where non-wood products, such as grasses, leaf litter and bedding materials, were collected, and where the use of timber for furniture production was applied to a minor extent. Although the plantations required regular silvicultural treatment protection, measures are mostly preferred by government authorities and local elites. Tab. 4 highlights the characteristics of each strategy, whereas all management approaches from traditional participatory, to evolutionary (trial and error), passive and active adaptive management were identified by the stakeholder groups.

- Management Strategy I (MS I): focuses mainly on protection measures (e.g., no grazing, making fire lines, patrolling by forest guards, no harvesting) and was proposed by traditional users, the old committee and elite members.

- Management Strategy II (MS II): focuses mainly on plantations to support the forest protection management regime and was proposed by executive committee members.
- Management Strategy III (MS III): allows a multiple use of natural resources introducing production-oriented measures and supporting the active inclusion of all members; it was proposed by executive members and hamlet representatives.

- Management Strategy IV (MS IV): focuses on a sustained sawn timber production and other ecosystem services by advocating new institutional arrangements; it was proposed by local facilitators dominated by young members.

\section{Evaluation of management strategies}

The total 71 users in 12 stakeholder subgroups carried out the qualitative assessment regarding the performance of all management strategies against each indicator. The stakeholders assessed the future effects of a management strategy if they would cause no change in, make a positive improvement in, or conflict with, the current situation (Tab. 5).

For the assessment of the management strategies the evaluation hierarchy of the AHP was used based on the 6 criteria and 44 indicators. The overall goal was to "select the best strategy with regard to livelihood enhancement and sustainable forest management" on top, the criteria and indicators on

Tab. 4 - Characteristics of the management strategies (MS I-IV).

\begin{tabular}{|c|c|c|c|c|}
\hline Elements & MS I & MS II & MS III & MS IV \\
\hline $\begin{array}{l}\text { Planning } \\
\text { approach }\end{array}$ & Traditional participatory & $\begin{array}{l}\text { Evolutionary (Trial } \\
\text { and Error) }\end{array}$ & Passive adaptive management & Active adaptive management \\
\hline $\begin{array}{l}\text { Management } \\
\text { strategy }\end{array}$ & Protection oriented & $\begin{array}{l}\text { Segregation } \\
\text { management }\end{array}$ & multi-purpose management & Sawn timber production \\
\hline $\begin{array}{l}\text { Forest } \\
\text { Management }\end{array}$ & $\begin{array}{l}\text { Protection, Forest } \\
\text { patrolling by forest } \\
\text { guards, Grazing control }\end{array}$ & $\begin{array}{l}\text { Plantation, Extraction } \\
\text { of dead, dying and di- } \\
\text { seased trees, rotational } \\
\text { thinning, no block-wise } \\
\text { management }\end{array}$ & $\begin{array}{l}\text { Light thinning, Selective har- } \\
\text { vesting, conservative harve- } \\
\text { sting, enrichment, introduce } \\
\text { block management system }\end{array}$ & $\begin{array}{l}\text { Clear-cut and selective system, thin- } \\
\text { ning and singling, Block-wise mana- } \\
\text { gement operation }\end{array}$ \\
\hline $\begin{array}{l}\text { Forest } \\
\text { governance }\end{array}$ & $\begin{array}{l}\text { Strict provision for } \\
\text { membership, fund } \\
\text { mobilization for infra- } \\
\text { structure }\end{array}$ & $\begin{array}{l}\text { Membership fee high, } \\
\text { Fund mobilization for } \\
\text { infrastructure and com- } \\
\text { munity development }\end{array}$ & $\begin{array}{l}\text { Easy access for members, } \\
\text { Fund mobilization for river- } \\
\text { bank management, Tourism } \\
\text { development, Wildlife conser- } \\
\text { vation }\end{array}$ & $\begin{array}{l}\text { No membership fee for poor users, } \\
\text { Fund mobilization for pro-poor, so- } \\
\text { cial security and forest management }\end{array}$ \\
\hline $\begin{array}{l}\text { Pro-poor } \\
\text { livelihood }\end{array}$ & $\begin{array}{l}\text { No clear vision, } \\
\text { discretion of CFUGC }\end{array}$ & $\begin{array}{l}\text { No specified pro- } \\
\text { gramme, Seed money } \\
\text { for poor people }\end{array}$ & $\begin{array}{l}\text { Allocate budget, well-being } \\
\text { ranking, introduce social se- } \\
\text { curity scheme }\end{array}$ & $\begin{array}{l}\text { Poverty reduction programme, Social } \\
\text { security scheme, specified budget } \\
\text { with programme }\end{array}$ \\
\hline $\begin{array}{l}\text { Enterprise } \\
\text { development }\end{array}$ & No provisions & $\begin{array}{l}\text { Income generation } \\
\text { Activities, Non-Timber } \\
\text { Forest Product planta- } \\
\text { tion }\end{array}$ & $\begin{array}{l}\text { Income generation Activities, } \\
\text { Skill development and training }\end{array}$ & $\begin{array}{l}\text { Timber-based industry ( Saw mill, } \\
\text { furniture), Income generation Activi- } \\
\text { ties, Market linkages }\end{array}$ \\
\hline $\begin{array}{l}\text { Forest } \\
\text { development }\end{array}$ & Nursery establishment & $\begin{array}{l}\text { Nursery establishment, } \\
\text { Plantations, Demon- } \\
\text { stration plot }\end{array}$ & $\begin{array}{l}\text { Nursery, Plantations, Demon- } \\
\text { stration plots, Forest manage- } \\
\text { ment training }\end{array}$ & $\begin{array}{l}\text { Nursery, forest management training, } \\
\text { Grassland management, Research plot }\end{array}$ \\
\hline $\begin{array}{l}\text { Community } \\
\text { development }\end{array}$ & $\begin{array}{l}\text { Checkdam, road mainte- } \\
\text { nance }\end{array}$ & $\begin{array}{l}\text { Seedling distribution to } \\
\text { Users }\end{array}$ & $\begin{array}{l}\text { Checkdam, Local facilitator } \\
\text { mobilization, Leadership de- } \\
\text { velopment, Training center }\end{array}$ & $\begin{array}{l}\text { Checkdam, Social mobilization, } \\
\text { Leadership development, Training } \\
\text { center }\end{array}$ \\
\hline $\begin{array}{l}\text { Monitoring } \\
\text { system }\end{array}$ & $\begin{array}{l}\text { No specified assessment } \\
\text { criteria, Progress report } \\
\text { in general assembly }\end{array}$ & $\begin{array}{l}\text { Progress and financial } \\
\text { report, Evaluation } \\
\text { criteria }\end{array}$ & $\begin{array}{l}\text { Self-monitoring and criteria } \\
\text { assessment and public audit } \\
\text { and public hearing }\end{array}$ & $\begin{array}{l}\text { Self-monitoring and criteria assess- } \\
\text { ment and public audit and public } \\
\text { hearing }\end{array}$ \\
\hline
\end{tabular}


Tab. 5 - Qualitative assessment of management strategies against indicators.

\section{Criteria/Indicators}

MS I MS II MS III

MS IV

Criterion 1: Compliance with all international, national and local laws under policy framework

I1.1 Payment of applicable taxes and fees

I1.2 Respect and enforcement of national and local laws

I1.3 Evaluation of conflicting laws

I1.4 Protection from illegal and unauthorized activities

I1.5 Consultation with professional, policy-makers and experts

I1.6 Documentation and reporting system to the appropriate authorities

Criterion 2: Silvicultural practices and other management systems

I2.1 Silvicultural management prescription

I2.2 Estimation of forest harvest

I2.3 Specific harvesting guidelines and techniques

I2.4 Ensuring the number of old trees in forest stands

I2.5 Promotion of plantation area

I2.6 Development and layout of plantations

I2.7 Control of encroachment and grazing

I2.8 Control of forest fire and minimization of forest damage

I2.9 Promotion of use of suitable tree species

++
++
+
+++
+
0

$\begin{array}{ccc}++ & ++ & + \\ ++ & ++ & + \\ + & ++ & + \\ ++ & ++ & + \\ + & ++ & + \\ 0 & ++ & +\end{array}$

+
+
++
++
++
++

Criterion 3: Encourage multiple forest products and services and a wide range of Environmental and Forest health

I3.1 Maintain ecosystem diversity

I3.2 Native species diversity

I3.3 Ecological assessment and diagnosis

I3.4 Promote environment impact assessment

I3.5 Maintain biodiversity

I3.6 Support conservation measures

I3.7 Wildlife management and habitat

I3.8 Water courses and other wetlands

-
$?$
-
+
0
0
+++
++
0

+
+
+
+
+
+
++
+
+

$\begin{array}{cc}++ & +++ \\ +++ & +++ \\ +++ & +++ \\ +++ & ++ \\ ++ & ++ \\ ++ & ++ \\ ++ & + \\ + & ++ \\ + & ++\end{array}$

Criterion 4: Appropriate enhancement of management plan

I4.1 Ensure users' participation in planning and implementation

I4.2 Implement management plans

I4.3 Revision and timeliness of management plan

I4.4 Review/approval of plan

I4.5 Develop management guidelines of enterprise development and other management plan

I4.6 Public availability of management plan

I4.7 Knowledge of forest resource use and management plan

$\begin{array}{cc}+ & + \\ + & + \\ + & + \\ ? & ? \\ 0 & ++ \\ + & ++ \\ ++ & ++ \\ ++ & ++\end{array}$

$\begin{array}{ccc}+ & ++ & + \\ + & ++ & ++ \\ + & ++ & ++ \\ ? & + & + \\ +++ & ++ & +++ \\ ++ & +++ & +++ \\ +++ & ++ & + \\ +++ & ++ & +\end{array}$

Criterion 5: Long-term social and economic well-being of local communities under community relations

I5.1 Promote participatory decision-making and social inclusion

I5.2 Ensure transparency

I5.3 Ensure collaboration within and among stakeholders

I5.4 Staff safety and health

I5.5 Special provision to unprivileged groups

I5.6 Encourage local processing and new markets

I5.7 Sharing in economic benefits of forest uses

I5.8 Income-generation activities

I5.9 Use of trained and experience persons

$\begin{array}{cccc}- & 0 & +++ & +++ \\ 0 & 0 & ++ & ++ \\ + & + & ++ & ++ \\ 0 & 0 & ++ & ++ \\ ? & ? & +++ & +++ \\ - & - & ++ & +++ \\ 0 & 0 & ++ & ++\end{array}$

Criterion 6: Regular monitoring and assessment

I6.1 Monitoring requirement

I6.2 Frequency and intensity of monitoring

I6.3 Data collection and use

I6.4 Incorporation of monitoring results into management plan

I6.5 Availability of monitoring results

$\begin{array}{cccc}- & + & +++ & +++ \\ - & + & +++ & +++ \\ + & + & ++ & ++ \\ 0 & +++ & ++ & + \\ - & - & ++ & +++ \\ ? & ? & ++ & ++ \\ 0 & 0 & ++ & ++ \\ - & + & ++ & +++ \\ 0 & + & + & + \\ & & & \\ + & + & ++ & ++ \\ + & + & ++ & ++ \\ + & 0 & + & + \\ ? & + & ++ & +++ \\ - & - & + & +++\end{array}$

the two next lower levels, and the four management strategies at the bottom (Fig. 2). Pairwise comparisons have been used to evaluate the performance of all management strategies according to each single indicator using the qualitative assessment by the stakeholders as input (see Tab. 5). The preferences for the criteria and indicators were derived based on the pairwise comparisons (Tab. 3).

The preferences derived for the criteria and indicator levels, done by pairwise compari- sons of the 12 individual stakeholder groups, were aggregated using the geometric mean to obtain group preferences for the local priorities. The priorities and ranks for the four management strategies, based on the geometric mean of the synthesized judgments with 
Tab. 6 - Priorities of management strategies based on geometric mean of the synthesized judgment with respect to the stakeholder groups.

\begin{tabular}{|c|c|c|c|c|c|c|c|c|c|c|}
\hline \multirow{2}{*}{$\begin{array}{l}\text { Management } \\
\text { strategies }\end{array}$} & \multicolumn{2}{|c|}{$\begin{array}{c}\text { Advisory members } \\
\text { groups }\end{array}$} & \multicolumn{2}{|c|}{$\begin{array}{c}\text { CFUGC members } \\
\text { groups }\end{array}$} & \multicolumn{2}{|c|}{$\begin{array}{c}\text { General user } \\
\text { groups }\end{array}$} & \multicolumn{2}{|c|}{$\begin{array}{c}\text { Local facilitators } \\
\text { groups }\end{array}$} & \multicolumn{2}{|c|}{ All stakeholders } \\
\hline & Priority & Rank & Priority & Rank & Priority & Rank & Priority & Rank & Priority & Rank \\
\hline MS I & 0.182 & 4 & 0.157 & 4 & 0.139 & 4 & 0.138 & 4 & 0.157 & 4 \\
\hline MS II & 0.192 & 3 & 0.178 & 3 & 0.175 & 3 & 0.172 & 3 & 0.181 & 3 \\
\hline MS III & 0.317 & 1 & 0.334 & 1 & 0.342 & 2 & 0.340 & 2 & 0.332 & 1 \\
\hline MS IV & 0.309 & 2 & 0.331 & 2 & 0.345 & 1 & 0.350 & 1 & 0.330 & 2 \\
\hline
\end{tabular}

Tab. 7 - Priorities of management alternatives based on the geometric mean of the synthesized preferences of stakeholders groups with re spect to the criteria. (C1): policy framework; (C2): silvicultural prescriptions; (C3): forest health; (C4): management plan; (C5): community relations; and (C6): monitoring and assessment.

\begin{tabular}{lcccccccccccc}
\hline \multirow{2}{*}{$\begin{array}{c}\text { Management } \\
\text { strategies }\end{array}$} & \multicolumn{2}{c}{ Criteria 1 } & \multicolumn{2}{c}{ Criteria 2 } & \multicolumn{2}{c}{ Criteria 3 } & \multicolumn{2}{c}{ Criteria 4 } & \multicolumn{2}{c}{ Criteria 5 } & Criteria 6 \\
\cline { 2 - 12 } & Priority & Rank & Priority & Rank & Priority & Rank & Priority & Rank & Priority & Rank & Priority & Rank \\
\hline MS I & 0.297 & 1 & 0.164 & 4 & 0.218 & 3 & 0.081 & 4 & 0.114 & 4 & 0.083 & 4 \\
MS II & 0.212 & 4 & 0.179 & 3 & 0.323 & 1 & 0.095 & 3 & 0.128 & 3 & 0.130 & 3 \\
MS III & 0.263 & 2 & 0.290 & 2 & 0.261 & 2 & 0.401 & 2 & 0.392 & 1 & 0.386 & 2 \\
MS IV & 0.228 & 3 & 0.367 & 1 & 0.198 & 4 & 0.424 & 1 & 0.366 & 2 & 0.401 & 1 \\
\hline
\end{tabular}

respect to the stakeholder groups, are shown in Tab. 6. For the advisory and committee members groups, MS III and MS IV are ranked first and second. For the general members and local facilitator groups, MS IV and MS III are ranked first and second, respectively. In considering the priority of all stakeholder groups it was found that MS III a passive adaptive management strategy focusing on a multiple use of natural resources and introducing production-oriented measures - was identified as the most preferable option, but in general MS III and MS IV are very close.

Fig. 3 shows the priorities of the management strategies assigned by different stakeholder groups at criteria level (C1-C6). In case of the advisory members group, they considered a similar perception as the CFUGC members, while MS I is the best option under the policy framework (C1), followed by MS IV under silvicultural prescriptions (C2), and MS III under Criteria 3-6. The priorities of the general members and local facilitators differed slightly. The local facilitators preferred MS IV as a best alternative under criteria 1,2 and 4 . In the case of general members groups, MS IV was the best option under criteria 2, 4 and 5, and MS
III at criteria 3 and 6 . In most of the cases, it becomes evident that MS III is either the best or second best option for all stakeholder groups.

Tab. 7 shows the performance of the management strategies with regard to the criteria level. Applying the geometric mean of the synthesized stakeholders' preferences reveals some interesting insights. MS IV was highly ranked in relation to the silvicultural operations (C2), management plan (C4) and monitoring and assessment (C6), and ranked with a low priority at forest health (C3). MS I was found as the best alternative with regard to policy framework (C1), whereas MS II was the best choice under management plan (C4). However, although management strategy III was ranked in second place for almost all criteria it seems to be the overall best compromise strategy (compare Tab. 6).

From Tab. 7 it can be found that MS I is the best alternative option according to policy framework $(\mathrm{C} 1)$, followed by MS III, MS IV and MS II as the least priority options. According to the $\mathrm{C} 2$ (Silvicultural practices and other management system), $\mathrm{C} 4$ (Appropriate management plan) and $\mathrm{C} 6$ (Regular monitoring and assessment), MS IV is the best management option, followed by MS III, MS II and MS I. The best option is MS II, taking environmental and forest health (C3) as the primary objective. MS III is the best management option considering only the long-term social and economic benefits to the local users (C4) as primary objective. In overall, MS III is the best management option for all stakeholders, whereas MS I has the lowest performance for all stakeholder groups.

\section{Discussion}

This study was meant to support the practical implementation of community forest management in the inner, central terai region of Nepal by utilizing MCA techniques for raising stakeholders' awareness and their commitment to the process. The approach brought the key stakeholders together and encouraged them to identify their problems and reflect critically on their attitude towards livelihood improvement. It was designed to assist decision-makers in structuring a decision problem, in generating and evaluating decision alternatives and analyze the tradeoffs of possible management strategies. In general, MCA techniques are considered to assist the decision-maker in solving complex decision problems (Keeney \& Raiffa 1976).
Fig. 2 - Analytic Hierarchical Process (AHP) model for the

evaluation of management strategies according to C\&I set.

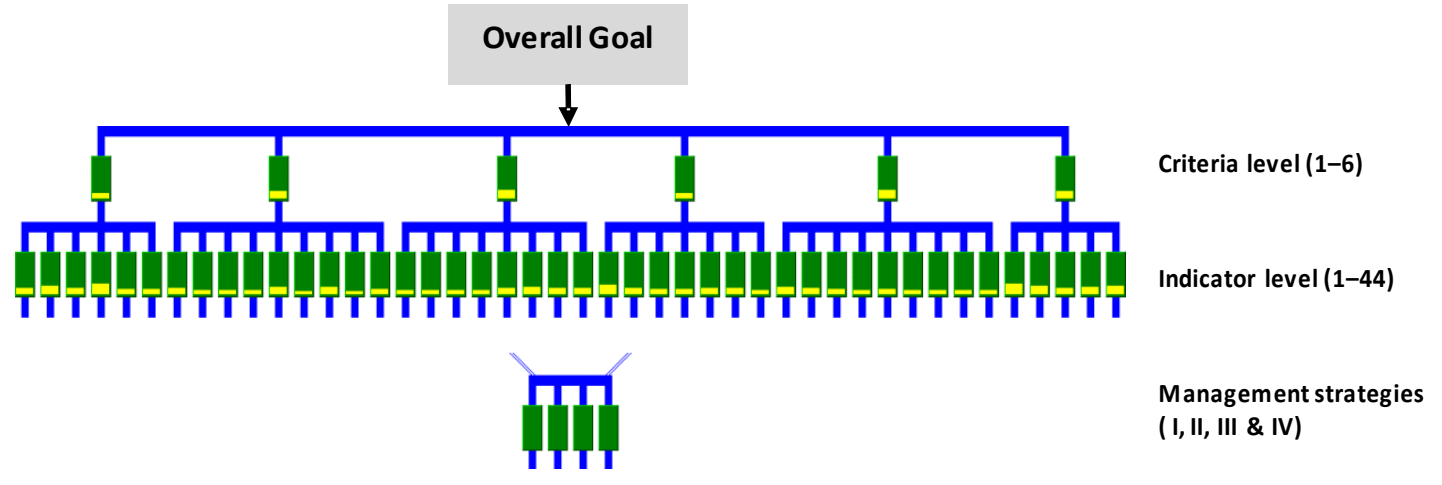


Fig. 3 - Priorities of the management strategies derived from the AHP from the perspective of different stakeholder groups. (A): Priorities of management strategies based on geometric mean of the synthesized judgment of one Advisory members group; (B): Priorities of management strategies based on geometric mean of the synthesized judgment of one Executive members group; (C): Priorities of management strategies based on geometric mean of the synthesized judgment of one General members group; (D): Priorities of management strategies based on geometric mean of the synthesized judgment of one Local facilitators group.
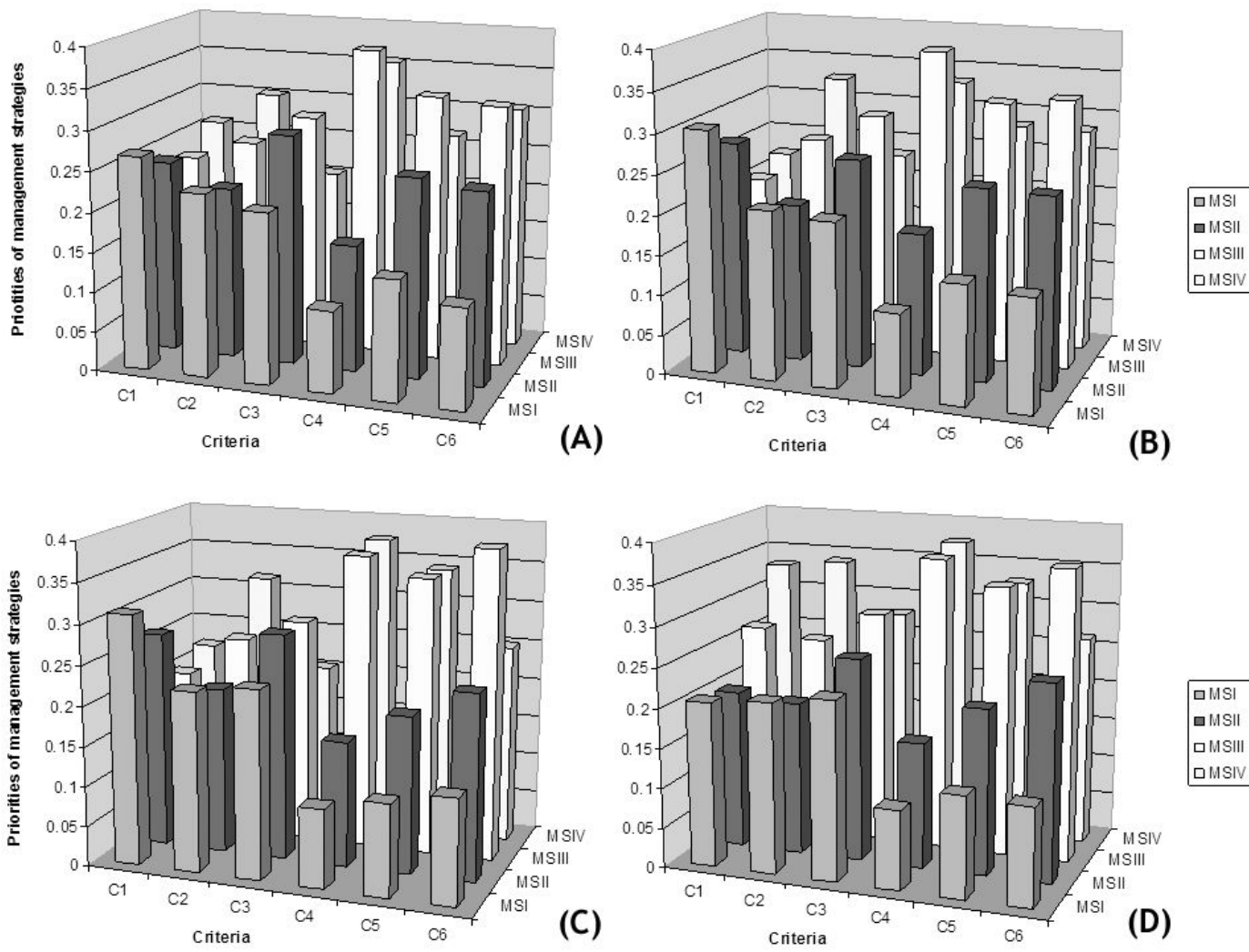

They are generally considered as promising in allowing a strong representation of stakeholder groups and incorporating their perceptions into the process (Mendoza \& Prabhu 2005). In this study the MCA helped to improve the decision-making process by increasing everyone understanding in the role of preferences for identifying promising management strategies and the importance of tradeoffs between various alternatives. How ever, application of monitoring, disregarding any methodological approach to explore the consequences of alternatives, may raise relevant problems: heavy reliance on managers experience and wisdom inherently and unreliably assumes that management conditions are stable over time (Corona \& Scotti 2011). The applied MCA process demonstrated the potential in selecting the most preferred forest management strategy which can best satisfy the objectives of community forest management. The four management strategies and the evaluation framework have been derived from the identified needs and expectations of the different socio-economic and institutional actors. When stakeholders are not fully involved in framing, analyzing, generating, and implementing management strategies to complex public problems, they might seek other ways of articulating and meeting their interests, hampering the decision process (Birkhof 2003). In this context, it became evident that compromise strategies have higher possibilities for realization when taking into account the different views of stakeholder groups. MS II was assessed as the best performing strategy under the criteria (C3) "Encourage multiple forest products and services" (Tab. 7), which was identified as the most relevant criteria for all stakeholder groups (Tab. 2). On the contrary, MS III was assessed as the best performing strategy under the criteria (C5) "Long-term social and economic well-being of local communities under community relations", whereas this criterion was seen to some extent as less important. However, despite the particularly good performance of some strategies, MS III was selected as an overall compromise strategy as it could reflect the major ideas of all stakeholders. MS III has a balanced mix of measures which allows to promote plantations, identify areas of protected areas, put emphasis on the documentation of ecological sensitive areas, as well as identify the potential of each vegetation type to meet the production, biodiversity conservation and other social issues for long-term SFM. The strategy includes effective measures to conserve rare, threatened and endangered species, to map wildlife corridors as well as to stop illegal hunting and trapping practices. The strategy allows promoting the design of plantations and technical measures to implement the operational plan. It also allows a passive adaptive management focusing on a multiple use of natural resources and introducing production-oriented measures, which will enhance livelihood of the local people and set new arrangements for power-sharing.

In the process of designing management strategies the participants were motivated to generate ideas for future improvements, whereas their vision of ideal future conditions was sometimes impractical and unachievable. Youth members generally oriented in the pathway of progressive change and simply ignored the existing power dynamics and institutional capacity of Community Forest User Group. Facilitators helped youth members and general users to develop new concepts as proposed by MS IV. In this context, the role of facilitators has been often described as important to incorporate the issues raised in the whole process, to support the generation of new ideas, alternative strategies and solutions to problems (McDougall et al. 2007). Although the MS IV alternative was built taking into account the objectives of CFM, it was far beyond the preferences of all stakeholder groups. In some cases, traditional users, local elites and CFUGC members hesitated to develop new management strategies because they wanted to maintain the status quo. Their proposed management strategies I and II did not take into account the objectives of the CFUG-like wider participation, livelihood enhancement or active forest management. Actually, the promoters of those strategies believed that it is enough to raise the problems and to solve them by applying more of the same. Therefore, MS III seemed to be promising as the best alternative management strategy. The feedback of 
the participants has shown that decisionmakers can be assisted by the MCA approach in evaluating management options effectively and generating ideas for the longterm strategic planning process of Community Forest Management, even under complex socio-economic and ecological conditions. It could be demonstrated that there is need to have clear, measurable, and agreedupon management objectives, by which to guide the decision making process and evaluate its performance, which in turn requires an acceptable range of management options and a flexible management environment that allows adaptations as learning occurs (Williams 2011b).

Decision-making in community-based institution is typically a complex task, characterized by trade-offs among socio-cultural, political, economic and environmental issues (Mendoza \& Prabhu 2005, Sheppard \& Meitner 2005). MCA techniques can be used to establish consensus and help to find mutually agreed compromises and management options, based on the contrary views of stakeholders. In practice, it has been difficult for the stakeholders to express their preferences for all criteria and indicators. Therefore three different techniques (rating, ranking, pair-wise comparison) have been ap plied to express the preferences for multiple objectives. Informal feedback from the stakeholders indicated that the rating and ranking was sometimes difficult, when the number of indicators under the criteria was high. In this context, the pair-wise comparisons helped to break down the choice of preferences to a single pair. Caution has to be used in applying any of the weighting procedures, as the process for elicitation of preferences can hamper the overall results (Sheppard \& Meitner 2005). However, the overall differences among the three techniques were quite low, which allowed to conclude that it was possible for the stakeholder groups to express their priorities in general. The AHP technique provided the possibility to analyze the effect of different stakeholder preferences. The outcomes were used not only to assess the robustness of the evaluation, but also to appraise the influence of each criterion in the selection of the best options. The use of preferences expressed for a given set of C\&I provide the opportunity for scenario analysis from different stakeholder perspectives (Herath 2004). In particular, such kind of scenario analysis applied is fundamental for attaining consensus and achieving technically defensible policy options (Bojórquez-Tapia et al. 2005, Dhar et al. 2008).

In combination with participatory tools, it is possible to provide data, information and structured knowledge as an essential requirement for decision-making (Nordström et al. 2010), as this promotes participation, nego- tiation, collaboration and social learning, and increases the adaptive collaborative management environment. In particular, Tuxill \& Nabhan (2001) and Myllyviita et al. (2011) highlight the importance of employing participatory activities that shift the involvement of local communities from passive to more active collaboration. The qualitative nature of the applied techniques in this study can be criticized for their lack of statistical meaning, but they give the participants and the facilitators time to deliberate; i.e., to consider and identify relevant knowledge (O'Neill 2001). This can improve rationality and transparency of the decisionmaking processes in general, which are recognized as highly important features of policy processes for some stakeholders (Kangas et al. 2010).

\section{Conclusions}

The research team and local facilitators were responsible for balancing the objectives of different stakeholder groups, supporting the user in structuring the decision-making process and evaluating alternative management options based on their own opinions. In hamlet meetings, executive committee meetings and C\&I development workshops, the participants had the opportunity to express their opinion about objectives, to identify decision problems and possible options to overcome them. Hence, the study promoted a shared understanding and thus increased the ability to change management practices in order to sustain desirable future expectations. However, the operational implementation of the MCA process requires the strong commitment of local elites and executive committee members (Timsina 2003). Wealthy and higher caste people (i.e., elites) have most of the decision-making and implementation power, resulting in inequitable decision-making processes and distribution of outcomes (Mahanty et al. 2006, Iversen et al. 2006). In particular, it was observed that forestry technicians and key decision-holders of CFUFC wanted to use their power to create obstacles and maintain the status quo, which provided more benefit for them. Nonetheless, the elites and committee members refused to forward the agreed management plan for the final approval to the local district office. Also the staff of District Forest Office (DFO) has considerable power to manipulate or delay the implementation based on their own interests, resulting in perhaps less active CFUG. Government officials may also need to change their attitude from a more traditional command and control approach to participatory forest management to assist and support community forest users in managing forest for their own multiple benefits. However, the general willingness for change is rather low; it seemed that once the executive committee members understood the principles of the MCA process they would facilitate the activities in an effective ways to combat such situation locally.

This study can serve as a milestone to utilize MCA techniques for collaborative-based decision-making processes in CFM in Nepal. An extensive review of the process and its methods to develop future strategies is required, not only to facilitate the process but also to promote an adaptive collaborative management on the long run. In order to integrate and implement adaptive management and multiple criteria decision-making process in community forest management of Nepal, it is essential to have a strong commitment from the responsible agencies for the revision of existing decision making procedures. Therefore, the role and responsibilities of implementing agencies, decision makers as well as policy makers need to be revised by improving their level of understanding, communication and commitment to a learning process including adaptive responses and reduce uncertainty over time. A continuing process of learning and refining management strategies can help to improve the forest conditions and livelihoods of local people by fostering the collaboration among stakeholders within innovative responses. Therefore, we propose that a combined application of MCA and participatory techniques will provide a powerful framework for adaptive management for a wide range of community forest management problems. However, to make use of such MCA techniques in community forest management in the future, there is a need for political will and commitment to engage in multi-stakeholder processes and provide support through organizational and personal means.

\section{Acknowledgements}

We would like to express our thanks to the Shree Gyneshwar community forest user groups and local experts, all of whom expressed their interest in our research activities. This study was supported by the Commission for Development Studies at the Austrian Academy of Science (KEF) and the Austrian Exchange Service (OEAD), by awarding Mr. Khadka a fellowship for his $\mathrm{Ph} . \mathrm{D}$ studies at the University of Natural Resources and Life Sciences (BOKU), Vienna.

\section{References}

Allen CR, Fontaine JJ, Pope KL, Garmestani AS (2011). Adaptive management for a turbulent future. Journal of Environmental Management 92 (5): 1339-1345. - doi: 10.1016/j.jenvman.2010. 11.019

Ananda J, Herath G (2005). Evaluating public risk preferences in forest land-use choices using multi-attribute utility theory. Ecological Economics 55 (3): 408-419. - doi: 10.1016/j.ecolecon.2004. 12.015

Antunes P, Santos R, Videira N (2006). Partici- 
patory decision making for sustainable development: the use of mediated modelling techniques. Land Use Policy 23 (1): 44-52. - doi: 10.1016/j. landusepol.2004.08.014

Armitage D, Berkes F, Doubleday N (2007). Adaptive co-management. Collaboration, learning and multilevel governance. University of British Columbia Press, Vancouver, BC, Canada.

Belton S, Stewart TJ (2002). Multiple criteria decision analysis. An integrated approach. Kluwer Academic Publishers, Massachusetts, USA.

Birkhof J (2003). Community conflict over water reuse. Perspectives from conflict analysis and resolution. Appendix C: Water reuse. In: "Understanding public perception and participation" (Hartley TW ed). Water Environment Research Foundation, Alexandria, VA, USA.

Blahna DJ, Yonts'-Shepard S (1989). Public involvement in resource planning: toward bridging the gap between policy and implementation. Society and Natural Resources 2 (1): 209-227. doi: 10.1080/08941928909380686

Bojórquez-Tapia LA, Sánchez-Colon S, Florez A (2005). Building consensus in environmental impact assessment through multicriteria modeling and sensitivity analysis. Environmental Management 36 (3): 469-481. - doi: 10.1007/s00267004-0127-5

Bolton M (1975). Royal Chitwan National park management plan, 1975-79. Project Working Document No. 2, HMG/UNDP/FAO National Parks and Wildlife Conservation Project, Kathmandu, Nepal.

Buck LE, Geisler CC, Schelhas J (2001). Biological diversity: balancing interests through adaptive collaborative management (Wollenberg E ed). CRC Press, New York, USA.

Carpenter S (1991). Solving community problems by consensus. Program for community problem solving, Washington, DC, USA.

Corona P, Scotti R (2011). Systemic silviculture, adaptive management and forest monitoring perspectives. L'Italia Forestale e Montana 66: 219 224. - doi: 10.4129/ifm.2011.3.05

Dhar A, Ruprecht H, Vacik H (2008). Population viability risk management (PVRM) for in-situ management of endangered tree species: a case study on a Taxus baccata L. population. Forest Ecology Management 255 (7): 2835-2845. - doi: 10.1016/j.foreco.2008.01.059

Friedmann J (1973). Retracking America: a theory of transactive planning. Anchor Press, Garden City, New York, USA.

Fürst C, Volk M, Makeschin F (2010). Squaring the circle? Combining models, indicators, experts and end-users in integrated land-use management support tools. Environmental Management 46 (6): 829-833. - doi: 10.1007/s00267010-9574-3

Glück P (1995). Criteria and indicators for sustainable forest management in Europe. Working Group S6, XX IUFRO World Congress, Tampere, Finland.

Gray B (1989). Collaborating: finding common ground for multiparty problems. Jossey-Bass
Publishers, San Francisco, CA, USA.

Gregory RS (2000). Valuing environmental policy options: a case study comparison of multiattribute and contingent valuation survey methods. Land Economics 76 (2): 151. - doi: 10.2307/ 3147222

Herath G (2004). Incorporating community objectives in improved wetland management: the use of the analytic hierarchy process. Journal of Environmental Management 70 (3): 263-273. doi: 10.1016/j.jenvman.2003.12.011

Hilborn R, Walters CJ (1992). Quantitative fisheries stock assessment: choice, dynamics and uncertainty. Kluwer Academic Publishers, Boston, Dordrecht, London. - doi: 10.1007/978-1-46153598-0

Hjortsø CN, Stræde S, Helles F (2006). Applying multi-criteria decision-making to protected areas and buffer zone management: a case study in the Royal Chitwan National Park, Nepal. Journal of Forest Economics 12 (2): 91-108. - doi: 10.1016/ j.jfe.2006.03.001

Holling CS (1978). Adaptive environmental assessment and management. John Wiley and Sons, London, UK.

ITTO (1992). Guidelines for the sustainable management of natural tropical forests. International Tropical Timber Organization, Yokohama, Japan.

ITTO (1993). Guidelines for the establishment and sustainable management planted tropical forests. International Tropical Timber Organization, Yokohama, Japan.

Iversen V, Chhetry B, Francis P, Gurung M, Kafle G, Pain A, Seeley J (2006). High value forests, hidden economies and elite capture: evidence from forest user groups in Nepal's terai. Ecological Economics 58 (1): 93-107. - doi: 10.1016/ j.ecolecon.2005.05.021

Jentoft S (1985). Models of fishery development. Marine Policy 9 (4): 322-331. - doi: 10.1016/ 0308-597X(85)90040-5

Kangas J (1999). The analytic hierarch process (AHP): standard version, forestry application and advances. In: "Multiple use of forests and other natural resources" (Helles F, Holten-Andersen P, Wichmann L eds). Kluwer Academic Publishers, Dordrecht, The Netherlands, pp. 96-105. - doi: 10.1007/978-94-011-4483-4

Kangas A, Laukkanen S, Kangas J (2006). Social choice theory and its applications in sustainable forest management' a review. Forest Policy and Economics 9 (1): 77-92. - doi: 10.1016/j.forpol. 2005.02.004

Kangas A, Saarinen N, Saarikoski H, Leskinen LA, Hujala T, Tikkanen J (2010). Stakeholder perspectives about proper participation for Regional Forest Programmes in Finland. Forest Policy and Economics 12 (3): 213-222. - doi: 10.1016/j.forpol.2009.10.006

Keeney RL, Raiffa H (1976). Decisions with multiple objectives: performances and value tradeoffs, Wiley, New York, USA.

Khadka C, Vacik H (2008). Applying adaptive collaborative management for social learning: a case study of community forestry in Nepal.
Journal of Universal Computer Science (J.UCS), pp. 101-108;

Khadka C, Vacik H (2012). Comparing a topdown and bottom-up approach in the identification of criteria and indicators for sustainable community forest management in Nepal. Forestry 85 (1): 145-158. - doi: 10.1093/forestry/ cpr068

Lindenmayer DB, Likens GE, Haywood A, Miezis L (2011). Adaptive monitoring in the real world: proof of concept. Trends in Ecology and Evolution 26 (12): 641-646. - doi: 10.1016/j.tree.2011. 08.002

Linkov I, Satterstrom F, Kiker G, Batchelor C, Bridges T, Ferguson E (2006). From comparative risk assessment to multi-criteria decision analysis and adaptive management: Recent developments and applications. Environment International 32 (8): 1072-1093. - doi: 10.1016/j.envint.2006.06.013

Mahanty S, Fox J, Nurse M, Stephen P, McLees L (2006). Hanging in the balance: equity in community based natural resource management in Asia. RECOFTC and East-West Centre, Bangkok, Thailand.

Malczewski J, Moreno-Sanchez R, Bojorquez-Tapia L, Ongay-Delhumeau E (1997). Multicriteria group decision-making model for environmental conflict analysis in the Cape Region, Mexico. Journal of Environmental Planning and Management 40 (3): 349-374. - doi: 10.1080/ 09640569712137

Mardle S, Pascoe S, Herrero I (2004). Management objective importance in fisheries: an evaluation using the Analytic Hierarchy Process (AHP). Environmental Management 33 (1): 111. - doi: 10.1007/s00267-003-3070-y

Martins H, Borges JG (2007). Addressing collaborative planning methods and tools in forest management. Forest Ecology and Management 248 (1-2): 107-118. - doi: 10.1016/j.foreco.2007. 02.039

Maser C (1996). Resolving environmental conflict: toward sustainable community development. St. Lucie Press, Delray Beach, Florida, USA.

McDonald-Madden E, Baxter PW, Fuller RA, Martin TG, Game ET, Montambault J, Possingham HP (2010). Monitoring does not always count. Trends in Ecology and Evolution 25 (10): 547-550. - doi: 10.1016/j.tree.2010.07.002

McDougall C, Kaski ACM Team, NewERA ACM Team, Forest Action (2007). Planning for the sustainability of forests through adaptive comanagement: Nepal country report. ACM Project/MoFSC Internal Research Report, CIFOR, Bogor, Jawa Barat, Indonesia.

MCPFE (1993). Ministerial conference on protection of forests in Europe. Conference Proceedings. Ministry of Agriculture and Forestry, Helsinki, Finland.

Mendoza G, Martins H (2006). Multi-criteria decision analysis in natural resource management: a critical review of methods and new modelling paradigms. Forest Ecology and Management 230 (1-3): 1-22. - doi: 10.1016/j.foreco.2006.03.023 
Mendoza GA, Prabhu R (2000). Multiple criteria decision making approaches to assessing forest sustainability using criteria and indicators: a case study. Forest Ecology and Management 131 (13): 107-126. - doi: 10.1016/S0378-1127(99) 00204-2

Mendoza GA, Prabhu R (2003). Qualitative multicriteria approaches to assessing indicators of sustainable forest resource management. Forest Ecology and Management 174 (1-3): 329-343. - doi: 10.1016/S0378-1127(02)00044-0

Mendoza GA, Prabhu R (2005). Combining participatory modeling and multi-criteria analysis for community-based forest management. Fores Ecology and Management 207 (1-2): 145-156. doi: 10.1016/j.foreco.2004.10.024

Myllyviita T, Hujala T, Kangas A, Leskinen P (2011). Decision support in assessing the sustainable use of forests and other natural resources - a comparative review. The Open Forest Science Journal 4 (1): 24-41. - doi: 10.2174/ 1874398601104010024

Nordström EM, Eriksson LO, Öhman K (2010). Integrating multiple criteria decision analysis in participatory forest planning: experience from a case study in northern Sweden. Forest Policy and Economics 12 (8): 562-574. - doi: 10.1016/j.forpol.2010.07.006

O’Neill J (2001). Representing people, representing nature, representing the world. Environment and Planning C: Government and Policy 19 (4) 483-500. - doi: 10.1068/c12s

Paulson D (1998). Collaborative management of public rangeland in Wyoming: lessons in comanagement. Professional Geographer 50: 301315. - doi: 10.1111/0033-0124.00122

Potapchuk WR (1991). New approaches to citizen participation: building consent. National Civic Review 80 (2): 158-168. - doi: 10.1002/(ISSN) 1542-7811

Prabhu R, Colfer CJP, Venkateswarlu P, Tan LC, Soekmadi R, Wollenberg E (1996). Testing criteria and indicators for the sustainable management of forests. Phase I: Final Report. CIFOR Special Publication, Jakarta, Indonesia.

Prabhu R, Colfer CJP, Dudley RG (1999). Guidelines for developing, testing and selecting criteria and indicators for sustainable forest management. The Criteria and Indicators Toolbox Series, no. 1, CIFOR, Bogor, Indonesia.

Prabhu R, Colfer CJP, Dudley RG (2000). Guidelines for developing, testing and selecting criteria and indicators for sustainable forest management: The Criteria and Indicators Toolbox Series, no. 1, CIFOR, Bogor, Indonesia.

Prabhu R, Ruitenbeek HJ, Boyle TJB, Colfer CJP (2001). Between voodoo science and adaptive management: In: "The role and research needs for indicators of sustainable forest management"
(Raison J, Brown A, Flinn D eds). Criteria and indicators for sustainable forest management. IUFRO Research Series, no. 7, CABI Publishing, Wallingford, UK, pp. 39-66. - doi: 10.1079/ 9780851993928.0000

Prato T, Herath G (2007). Multiple-criteria decision analysis for integrated catchment management. Ecological Economics 63 (2-3): 627-632. doi: 10.1016/j.ecolecon.2007.01.003

Ramanathan R (2001). A note on the use of the analytic hierarchy process for environmental impact assessment. Journal of Environmental Management 63 (1): 27-35. - doi: 10.1006/jema. 2001.0455

Reed MG (1995). Cooperative management of environmental resources: a case study from northern Ontario, Canada. Economic Geography 71 (2): 132. - doi: 10.2307/144355

Ritchie B, McDougall C, Haggith M, De Oliveira NB (2000). Criteria and Indicators role of institutions in forest management. Development and Change 53 (3): 435-461.

Saaty TL (1977). A scaling method for priorities in hierarchical structures. Journal of Mathematical Psychology 15 (3): 234-281. - doi: 10.1016/ 0022-2496(77)90033-5

Saaty TL (2008). Decision making with the analytic hierarchy process. International Journal of Services Sciences 1 (1): 83. - doi: 10.1504/ IJSSCI.2008.017590

Schmoldt D, Kangas J, Mendoza G, Pesonen M (2001). The analytic hierarchy process in natural resource and environmental decision making, Managing Forest Ecosystems Series, vol. 3. Kluwer, Dordrecht, Boston, London.

Schreiber ES, Bearlin AR, Nicol SJ, Todd CR (2004). Adaptive management: a synthesis of current understanding and effective application. Ecological Management and Restoration 5 (3): 177-182. - doi: 10.1111/emr.2004.5.issue-3

Sheppard SR, Meitner M (2005). Using multi-criteria analysis and visualisation for sustainable forest management planning with stakeholder groups. Forest Ecology and Management 207 (12): 171-187. - doi: 10.1016/j.foreco.2004.10.032 Susskind L, Ozawa C (1985). Mediating public disputes: obstacles and possibilities. Journal of Social Issues 41 (2): 145-159.

Susskind L, Cruiskshank J (1987). Breaking the impasse: consensual approaches to resolving public disputes. Basic Books, New York, USA.

Timsina PN (2003). Promoting social justice and conserving montane forest environments: a case study of Nepal's community forestry programme. The Geographical Journal 169 (3): 236242. - doi: 10.1111/1475-4959.00087

Tuxill J, Nabhan P (2001). People, plants and protected areas: a guide to in-situ management. Earthscan, London, UK.
Vacik H, Lexer MJ (2001). Application of a spatial decision support system in managing the protection forests of Vienna for sustained yield of water resources. Forest Ecology and Management 143 (1-3): 65-76. - doi: 10.1016/S03781127(00)00506-5

Vacik H, Bernhard W, Felix H, Josef H (2001). Importance of impact on forest ecosystems for a sustainable use and maintenance of biodiversity. In: Proceedings of the " 6 th International Symposium on the Analytical Hierarchy Process" (Dellmann K ed). ISAHP, Berne (Switzerland) 2-4 August 2001, pp. 501-510.

Walters CJ, Hilborn R (1978). Ecological optimization and adaptive management. Annual Review of Ecology and Systematics 9 (1): 157-188. - doi: 10.1146/ecolsys. 1978.9.issue-1

Walters CJ (1986). Adaptive management of renewable resources. McGraw Hill, New York, NY, USA.

Walters CJ (1997). Challenges in adaptive management of riparian and coastal ecosystems. Conservation Ecology 1 (2): 1 [online] URL: http://www.consecol.org/vol1/iss2/art1/

Wijewardana D (2008). Criteria and indicators for sustainable forest management: The road travelled and the way ahead. Ecological Indicators 8 (2): 115-122. - doi: 10.1016/j.ecolind.2006.11. 003

Williams BK (2011a). Adaptive management of natural resources' framework and issues. Journal of Environmental Management 92 (5): 13461353. - doi: 10.1016/j.jenvman.2010.10.041

Williams BK (2011b). Passive and active adaptive management: approaches and an example. Journal of Environmental Management 92 (5): 13711378. - doi: 10.1016/j.jenvman.2010.10.039

Wolfslehner B, Vacik H (2008). Evaluating sustainable forest management strategies with the Analytic Network Process in a Pressure-StateResponse framework. Journal of Environmental Management 88 (1): 1-10. - doi: 10.1016/j.jenvman.2007.01.027

Wolfslehner B, Vacik H, Lexer MJ (2005). Application of the analytic network process in multi-criteria analysis of sustainable forest management. Forest Ecology and Management 207 (12): 157-170. - doi: 10.1016/j.foreco.2004.10.025 Wondolleck J, Yaffee S (2000). Making collaboration work: Lessons from innovation in natural resource management. Island Press, Covelo, California, USA

Woodley SG, Alward LI, Gutierrez T, Hoekstra B, Holt L, Livingston J, Loo A, Skibicki C, Williams, Wright P (1998). North american test of criteria and indicators of sustainable forestry. Final Report, vol. 1, CIFOR, Bogor, Indonesia, pp. 127. 